\title{
Recapitulation of Normal and Abnormal BB Rat Immune System Development in scid Mouse/Rat Lymphohemopoietic Chimeras
}

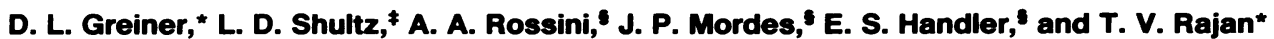 \\ ${ }^{*}$ Department of Pathology, University of Connecticut Health Center, Farmington, Connecticut 06030; ${ }^{\ddagger}$ The Jackson Laboratory, Bar \\ Harbor, Maine 04609; and 'Department of Medicine, University of Massachusetts Medical School, Worcester, Massachusetts 01655
}

\begin{abstract}
Mice homozygous for the mutation "severe combined immune deficiency" (C.B17-scid/scid) lack functional T and B lymphocytes and readily accept tumor xenografts. Partial lymphohemopoietic scid/human and mouse/rat chimeras have been described, but complete chimerization with thymic engraftment and generation of donor-origin thymocytes has not been achieved. We now report that low-dose irradiation permits the engraftment of BB rat fetal liver stem cells in scid recipients. We observed that BB rat fetal liver cells injected into irradiated scid mice establish a rat hemopoietic system in the scid mouse bone marrow and populate the scid mouse thymus. These stem cells generated rat-origin thymocytes that migrated to the scid mouse spleen, a peripheral lymphoid organ. Finally, we found that xenogeneic chimeras created using fetal liver cells from the abnormal (lymphopenic, diabetes prone) subline of BB rats recapitulated both the quantitative and phenotypic abnormalities of the donor rat. Xenogeneic lymphohemopoietic chimeras established in scid mice may provide a powerful new tool in the study of immune system development and autoimmunity. ( $J$. Clin. Invest. 1991. 88:717-719.) Key words: scid mouse • BB/ Wor rat $\bullet$ lymphopoiesis $\bullet$ chimera $\bullet$ immune system development
\end{abstract}

\section{Introduction}

Xenogeneic chimerism is a particularly useful tool in immunology for the study of diverse problems in autoimmunity, transplantation, and tumor biology. Previous attempts to establish xenogeneic mouse/rat chimeras have met with limited success. In these studies, heavily irradiated immunocompetent mice were injected with rat $\mathrm{T}$ cell-depleted bone marrow cells, but the resultant chimeras failed to develop rat-origin thymocytes or peripheral $\mathrm{T}$ cells (1). Donor-origin thymocytes or $\mathrm{T}$ cells also failed to develop in similarly pretreated rat recipients of mouse stem cells (2).

Mice homozygous for the mutation "severe combined immune deficiency" (C.B17-scid/scid) lack functional T and B lymphocytes and readily accept tumor xenografts (3-5). Functional rearrangement of $T$ and $B$ cell antigen-specific receptors fails to occur at the VDJ recombination step in scid mice (6).

Address correspondence to D. L. Greiner.

Received for publication 16 April 1991.

J. Clin. Invest.

(C) The American Society for Clinical Investigation, Inc.

$0021-9738 / 91 / 08 / 0717 / 03 \$ 2.00$

Volume 88, August 1991, 717-719
This may be due in part to a defect in a recombinase enzyme and/or a more generalized defect in DNA repair $(6,7)$. As a result, there are few circulating lymphocytes and a preponderance of monocytes and polymorphonuclear leukocytes. The phenotype of the few thymocytes that do develop in scid mice are CD4, CD8 (8). The concomitant B cell deficiency results in serum Ig concentrations that do not exceed $0.2 \mu \mathrm{g} / \mathrm{ml}$ (3). Peripheral lymphoid organs are only $\sim 10 \%$ of normal size and are populated largely by stromal cells. The thymus of scid mice lacks cortical architecture. The rudimentary thymic medulla is comprised principally of fibroblasts and epithelial cells, and very few lymphoid elements are present (3). Macrophage and natural killer cell function are normal or elevated in scid mice (9), and a hematocrit of $40-50 \%$ and adequate platelet counts attest to normal hemopoietic development.

C.B17-scid mice have held out the promise of a superior host for xenogeneic hematopoietic stem cells. Partial lymphohemopoietic scid/human (10-13) and mouse/rat (1) chimeras have been described, but complete chimerization with thymic engraftment and generation of donor-origin thymocytes has not been achieved. Lymphohemopoietic scid mouse/human chimeras have been described (10-13). Mosier et al. demonstrated that human peripheral blood lymphocytes can be engrafted into unirradiated scid mice without evidence of graft vs. host disease $(12,14)$, but other investigators have not achieved comparable levels of engraftment (13). McCune et al. (11) and Barry et al. (15) have also engrafted human lymphocytes in scid mice using fetal liver and/or fetal thymus. Reproducibility and the extent of chimerism in these systems has been variable. In the studies of McCune et al. and Barry et al., the chimerism produced was largely limited to the subrenal capsule into which the grafts were transplanted.

We now report that low-dose irradiation permits the engraftment of rat fetal liver stem cells in the bone marrow of the recipients. We chose to study scid/rat xenogeneic chimeras using BB rat fetal liver donors. "Diabetes prone" (DP) ${ }^{1}$ BB rats develop spontaneous autoimmune diabetes mellitus and lymphocytic thyroiditis (16). They are severely lymphopenic (17) and lack $\mathrm{T}$ cells that express the RT6 surface alloantigen (18, 19). Coisogenic “diabetes resistant" (DR) BB rats are not lymphopenic, possess RT6.1 ${ }^{+} \mathrm{T}$ cells, and do not develop islet or thyroid pathology (20). We observed that DP or DR-BB rat fetal liver cells injected into irradiated scid mice establish a rat hemopoietic system in the scid mouse bone marrow and populate the scid mouse thymus. These stem cells generate rat-origin thymocytes that migrate to the scid mouse spleen, a periph-

1. Abbreviations used in this paper: DP, diabetes prone; DR, diabetes resistant. 
Table I. BB Rat Hemopoietic Cells in Bone Marrow of Irradiated scid Mice

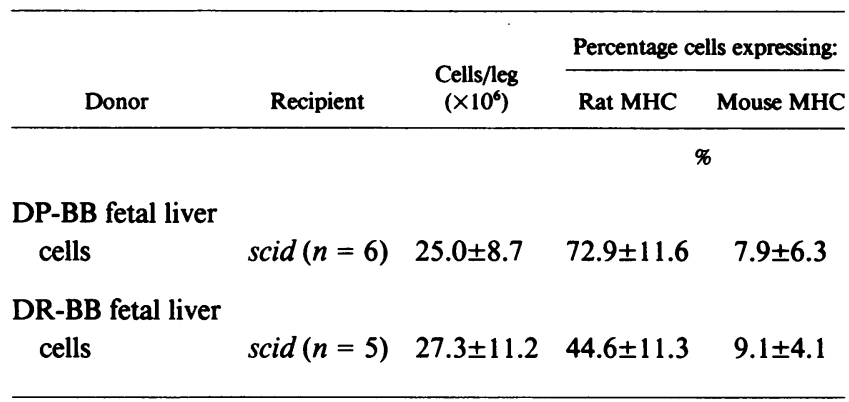

The relative proportion of rat or mouse-origin lymphohemopoietic cells in the bone marrow, thymus, and spleen of DP or DR rat fetal liver reconstituted scid mice was determined 6-7 wk postirradiation and reconstitution with $5 \times 10^{6}$ day 19 gestation rat fetal liver cells. Cell counts expressed as cells per leg were obtained by flushing one tibia and one femur from each animal. The relative proportion of each cell population was determined by indirect immunofluorescence by flow cytometry.

eral lymphoid organ, where the lymphopenia and $\mathrm{RT}^{+} \mathrm{T}$ cell defect of the DP rat are recapitulated. These latter observations trace the ontogenetic defect in DP rat lymphopoiesis to the level of fetal liver stem cells.

\section{Methods}

Animals. C.B17-scid/scid mice were obtained from a research colony at the Jackson Laboratory, Bar Harbor, ME. DP and DR BB/Wor rats were obtained from the University of Massachusetts, Worcester.

Reagents. The hybridoma clone 34212 producing anti-H-2 (C.B17) mouse MHC monoclonal antibody is maintained in our laboratory (21). Antibody against the $\mathrm{RT} 1^{\mathrm{u}} \mathrm{BB}$ rat $\mathrm{MHC}$ was kindly provided by Dr. Heinz Kunz, University of Pittsburgh, Pittsburgh, PA. Anti-Ly5 (mouse pan-lymphocyte) was obtained from Dupont/New England Nuclear, Boston, MA. MRC OX19 (anti-rat CD5), MRC W3/ 25 (anti-rat CD4), MRC OX8 (anti-rat CD8) monoclonal antibodies were obtained from Accurate Chemical and Scientific, Westbury, NY) (22). DS4.23 anti-RT6.1 (rat peripheral T cell alloantigen) was prepared from hybridoma supernatant maintained in our laboratory (18). All antibodies used in these studies have been tested for xenospecificity, and the level of cross-reactivity is $<2 \%$ (data not presented).

Protocol. In these studies, scid mice $30 \mathrm{~d}$ old were given 300 rads of gamma irradiation and then reconstituted with DP-BB or DR-BB fetal liver cells. The relative proportion of rat or mouse-origin lymphohemopoietic cells in the bone marrow, thymus, and spleen of DP or DR rat fetal liver reconstituted scid mice was determined 6-7 wk after irradiation with 300 rads and reconstitution by intravenous injection of
$5 \times 10^{6}$ day 19 gestation rat fetal liver cells. Cell counts expressed as cells per leg were obtained by flushing one tibia and one femur from each animal. The relative proportion of each cell population was determined by indirect immunofluorescence by flow cytometry on a FACS scan (Becton Dickinson Co., Sunnyvale, CA).

\section{Results}

When studied at necropsy 6-8 wk after reconstitution with fetal liver cells, $45-73 \%$ of bone marrow cells in both types of scid/BB chimeras (DR and DP) could be identified as rat cells expressing the BB rat $\mathrm{RT}^{\mathrm{u}}{ }^{\mathrm{u}} \mathrm{MHC}$ haplotype (Table I). $<10 \%$ of their bone marrow cells expressed the H-2d C.B17-mouse MHC antigen. The origin and phenotype of the non-MHC expressing bone marrow cells in this novel system is not yet known.

The extent of chimerism observed in bone marrow extended to the thymus where both DP and DR-BB thymocytes were observed. The absolute number of thymocytes was greater in mice reconstituted with DR as opposed to DP fetal liver, but $\approx 50 \%$ of thymic cell populations in both DP and DR reconstituted scid mouse expressed the RT ${ }^{u}$ rat MHC antigen (Table II). Whether this difference in absolute numbers is due to the expression of a defect that is now evident in this unique experimental system or due to the use of earlier, more immature stem cells is unknown (19). $<1 \%$ of thymic cells expressed the mouse pan lymphocyte antigen Ly5. The cells present in these scid mouse chimeric thymuses expressed the rat $\mathrm{T}$ cell differentiation antigens CD5, CD4, and CD8.

Of particular interest were the absolute numbers and phenotypes of rat-origin spleen cells in these chimeras. As in the thymus, the absolute number of splenocytes was greater in mice reconstituted with DR as opposed to DP fetal liver (Table III). $>90 \%$ of both DP and DR reconstituted scid mouse spleen cells expressed the $R T 1^{u}$ rat $\mathrm{MHC}$, and only 2-6\% chimeric splenocytes expressed mouse Ly5. Surface rat $\mathrm{Ig}^{+}$cells, presumably rat $\mathrm{B}$ cells, were present to a comparable extent among both DP and DR reconstituted scid splenocyte populations, but, more importantly, the percentage of rat $\mathrm{CD5}^{+}$spleen cells was more than fivefold greater in the scid/DR than in the scid/ DP chimeras. Similarly the percentage of rat $\mathrm{CD} 4^{+}$and $\mathrm{CD} 8^{+}$ splenocytes was also three- to fourfold greater in the scid/DR animals. Finally, $8 \%$ of spleen cells in DR reconstituted scid mice expressed the rat RT6.1 alloantigen, but no RT6 ${ }^{+}$cells could be detected in the spleens of DP reconstituted scid mice.

We determined the level of circulating rat Ig in the scid/BB rat chimeras by ELISA (23). In DR reconstituted scid mice, the serum concentration rat Ig was $25.1 \pm 3.4 \mathrm{mg} / \mathrm{ml}$. In contrast, the serum concentration of rat Ig in the serum of scid mice

Table II. BB Rat Lymphocytes in the Thymus of Irradiated scid Mice

\begin{tabular}{|c|c|c|c|c|c|c|c|}
\hline \multirow[b]{2}{*}{ Donor } & \multirow[b]{2}{*}{ Recipient } & \multirow[b]{2}{*}{$\begin{array}{l}\text { Cells/thymus } \\
\left(\times 10^{6}\right)\end{array}$} & \multicolumn{5}{|c|}{ Percentage cells expressing: } \\
\hline & & & $\begin{array}{c}\text { Rat MHC } \\
\text { RT1 }^{\circ}\end{array}$ & $\begin{array}{l}\text { Rat CD5 } \\
\text { (OX19) }\end{array}$ & $\begin{array}{l}\text { Rat CD4 } \\
\text { (W3/25) }\end{array}$ & $\begin{array}{c}\text { Rat CD8 } \\
\text { (OX8) }\end{array}$ & $\begin{array}{c}\text { Mouse } \\
\text { (Ly5) }\end{array}$ \\
\hline & & & $\%$ & $\%$ & $\%$ & $\%$ & $\%$ \\
\hline DP-BB fetal liver cells & $\operatorname{scid}(n=6)$ & $9.2 \pm 3.9$ & $44.8 \pm 23.4$ & $44.1 \pm 29.6$ & $21.8 \pm 21.7$ & $28.6 \pm 23.8$ & $<1.0$ \\
\hline DR-BB fetal liver cells & $\operatorname{scid}(n=5)$ & $28.8 \pm 4.6$ & $50.3 \pm 8.0$ & $71.9 \pm 10.0$ & $60.1 \pm 11.1$ & $45.8 \pm 13.4$ & $<1.0$ \\
\hline
\end{tabular}

Mice are the same as those in Table I. 
Table III. BB Rat Lymphocytes in Spleen of Irradiated scid Mice

\begin{tabular}{|c|c|c|c|c|c|c|c|c|c|}
\hline \multirow[b]{2}{*}{ Donor } & \multirow[b]{2}{*}{ Recipient } & \multirow[b]{2}{*}{$\begin{array}{l}\text { Cells/spleen } \\
\left(\times 10^{6}\right)\end{array}$} & \multicolumn{7}{|c|}{ Percentage cells expressing: } \\
\hline & & & $\begin{array}{c}\text { Rat MHC } \\
\left(\mathrm{RT}^{4} 1^{4}\right)\end{array}$ & $\begin{array}{l}\text { Rat CD5 } \\
\text { (OX19) }\end{array}$ & $\begin{array}{l}\text { Rat CD4 } \\
\text { (W3/25) }\end{array}$ & $\begin{array}{c}\text { Rat CD8 } \\
\text { (OX8) }\end{array}$ & $\begin{array}{c}\text { Rat } \\
\text { RT6.1 }\end{array}$ & $\begin{array}{l}\text { Rat B cells } \\
\text { (sIg) }\end{array}$ & $\begin{array}{c}\text { Mouse } \\
\text { (Ly5) }\end{array}$ \\
\hline & & & $\%$ & $\%$ & $\%$ & $\%$ & $\%$ & $\%$ & $\%$ \\
\hline DP-BB fetal liver cells & $\operatorname{scid}(n=6)$ & $16.5 \pm 15.0$ & $90.1 \pm 4.4$ & $6.8 \pm 3.8$ & $7.7 \pm 4.0$ & $7.2 \pm 2.5$ & $<1$ & $29.1 \pm 10.2$ & $1.7 \pm 1.1$ \\
\hline DR-BB fetal liver cells & $\operatorname{scid}(n=5)$ & $23.3 \pm 6.1$ & $90.3 \pm 3.2$ & $37.8 \pm 6.1$ & $30.6 \pm 5.1$ & $22.8 \pm 5.6$ & $8.4 \pm 3.6$ & $40.2 \pm 6.0$ & $5.6 \pm 1.7$ \\
\hline
\end{tabular}

Mice and reagents are the same as those in Tables I and II.

reconstituted with DP fetal liver cells was only $2.2 \pm 1.9 \mathrm{mg} / \mathrm{ml}$, perhaps reflecting a relative lack of rat helper $\mathrm{T}$ cell function in these animals. $<0.1 \mathrm{mg} / \mathrm{ml}$ mouse Ig was detected in any of these chimeras. Histological analysis of necropsy specimens revealed no evidence of GVHD in the liver, and neither pancreatitis nor insulitis were evident. Finally, we studied one lower radiation dose (100 rads) and observed only low levels of chimerism in scid recipients ( $<10 \%$ rat cells in bone marrow, thymus, and spleen).

\section{Discussion}

These results demonstrate that low-dose irradiation of scid mice before reconstitution with a xenogeneic stem cell graft greatly enhances the process of chimerization. More interestingly, the data demonstrate that DP or DR-BB rat fetal liver cells establish a rat hemopoietic system in the scid mouse bone marrow that differentially populates the scid mouse thymus. These stem cells generate rat-origin thymocytes that migrate to the scid mouse spleen, where the lymphopenia and $\mathrm{RT}^{+} \mathrm{T}$ cell defect of the DP rat are recapitulated. These latter observations trace the DP's ontogenetic defect in lymphopoiesis to the level of fetal liver stem cells, rule out the influence of host environmental factors in expression of the DP T cell developmental defect, and offer the promise of more detailed understanding of the defective immune system of the DP rat in the future.

The xenogeneic scid/rat chimera has many potential experimental applications. These include studies of the development of xenogeneic tolerance and MHC restriction and the role of accessory cells of bone marrow derived-origin (in this case, rat origin) versus the role of epithelium (mouse origin) in both positive and negative selection. The use of low-dose irradiation may facilitate the grafting of human lymphohemopoietic stem cells in scid mice.

\section{Acknowledgments}

We thank Bruce Gott, Patricia Porte, Anita Wayne, Kathleen Fitzgerald, Linda Paquin, Linda Leehy, and Olita Treimanis for assistance.

This work was supported in part by grants DK36024, DK41235, DK25036, AI30046, AI30389, and CA20408 from the National Institutes of Health.

\section{References}

1. Sykes, M., and D. H. Sachs. 1988. Mixed allogeneic chimerism as an approach to transplantation tolerance. Immunol. Today. 9:23-27.

2. Wade, A. C., P. H. Luckert, S. Tazume, J. L. Niedbalski, and M. Pollard 1987. Characterization of xenogeneic mouse-to-rat bone marrow chimeras. I. Examination of hematologic and immunologic function. Transplantation (Baltimore). 44:88-92.
3. Bosma, G. C., R. P. Custer, and M. J. Bosma. 1983. A severe combined immunodeficiency mutation in the mouse. Nature (Lond.). 301:527-530.

4. Bosma, G. C., M. T. Davisson, N. R. Ruetsch, H. O. Sweet, L. D. Shultz and M. J. Bosma. 1989. The mouse mutation severe combined immune deficiency (scid) is on chromosome 16. Immunogenetics. 29:54-57.

5. Phillips, R. A., M. A. S. Jewett, and B. L. Gallie. 1989. Growth of human tumors in immune-deficient scid mice and nude mice. Curr. Top. Microbiol. Immunol. 152:259-263.

6. Malynn, B. A., T. K. Blackwell, G. M. Fulop, G. A. Rathbun, A. J. W. Furley, P. Ferrier, L. B. Heinke, R. A. Phillips, G. D. Yancopoulos, and F. W. Alt 1988. The scid defect affects the final step in the immunoglobulin VDJ recombinase mechanism. Cell. 54:453-460.

7. Fulop, G. M., and R. A. Phillips. 1990. The scid mutation in mice causes a general defect in DNA repair. Nature (Lond.). 347:479-482.

8. Ansell, J. D., and G. J. Bancroft. 1989. The biology of the SCID mutation. Immunol. Today. 10:322-325.

9. Tutt, M. M., W. Schuler, W. A. Kuziel, P. W. Tucker, M. Bennett, M. J. Bosma, and V. Kumar. 1987. T cell receptor genes do not rearrange or express functional transcripts in natural killer cells of scid mice. J. Immunol. 138:23382344.

10. Reddy, S., D. Piccione, H. Takita, and R. B. Bankert. 1987. Human lung tumor growth established in the lung and subcutaneous tissue of mice with severe combined immunodeficiency. Cancer Res. 47:2456-2460.

11. McCune, J. M., R. Namikawa, H. Kaneshima, L. D. Shultz, M. Lieberman, and I. L. Weissman. 1988. The scid-hu mouse: murine model for the analysis of human hematolymphoid differentiation and function. Science (Wash. DC). 241:1632-1639.

12. Mosier, D. E., R. J. Gulizia, S. M. Baird, and D. B. Wilson. 1988. Transfer of a functional human immune system to mice with severe combined immunodeficiency. Nature (Lond.). 335:256-259.

13. Krams, S. M., K. Dorshkind, and M. E. Gershwin. 1989. Generation of biliary lesions after transfer of human lymphocytes into severe combined immunodeficient (scid) mice. J. Exp. Med. 170:1919-1930.

14. Mosier, D. E., R. J. Gulizia, S. M. Baird, and D. B. Wilson. 1989. On the scids? Nature (Lond.). 338:211.

15. Barry, T. S., D. M. Jones, C. B. Richter, and B. F. Haynes. 1991. Successful engraftment of human postnatal thymus in severe combined immune deficient (scid) mice: differential engraftment of thymic components with irradiation versus anti-asialo GM-1 immunosuppressive regimens. J. Exp. Med. 173:167180

16. Mordes, J. P., J. Desemone, and A. A. Rossini. 1987. The BB rat. Diabetes/Metab. Rev. 3:725-750.

17. Elder, M. E., and N. K. Maclaren. 1983. Identification of profound peripheral $\mathrm{T}$ lymphocyte immunodeficiencies in the spontaneously diabetic BB rat. $J$. Immunol. 130:1723-1731.

18. Greiner, D. L., E. S. Handler, K. Nakano, J. P. Mordes, and A. A. Rossini 1986. Absence of the RT-6 T cell subset in diabetes-prone BB/W rats. J. Immunol. 136:148-151.

19. Angelillo, M., D. L. Greiner, J. P. Mordes, E. S. Handler, N. Nakamura, U. McKeever, and A. A. Rossini. 1988. Absence of RT6 ${ }^{+}$T cells in diabetesprone BioBreeding/Worcester rats is due to genetic and cell developmental defects. J. Immunol. 141:4146-4151.

20. Like, A. A., and A. A. Rossini. 1984. Spontaneous autoimmune diabetes mellitus in the BioBreeding/Worcester rat. Surv. Synth. Pathol. Res. 3:131-138.

21. Ozato, K., N. M. Mayer, and D. H. Sachs. 1982. Monoclonal antibodies to mouse major histocompatibility complex antigens. Transplantation (Baltimore). 34:113-120.

22. Brideau, R. J., P. B. Carter, W. R. McMaster, D. W. Mason, and A. F. Williams. 1980. Two sets of rat $T$ lymphocytes defined with monoclonal antibodies. Eur. J. Immunol. 10:609-615.

23. Nelson, F. K., D. L. Greiner, L. D. Shultz, and T. V. Rajan. 1991. The immunodeficient scid mouse as a model for human lymphatic filariasis. J. Exp. Med. 173:659-664. 